\title{
A Luta pelo espaço do Oficina
}

\author{
The Oficina's Fight for a space \\ Tommy Della Pietra
}

Tommy Della Pietra

Fez parte da Associação Teat[r]o Oficina Uzyna Uzona de 1998 a 2013. Atualmente é assistente na Gerência de Ação Cultural do Sesc São Paulo

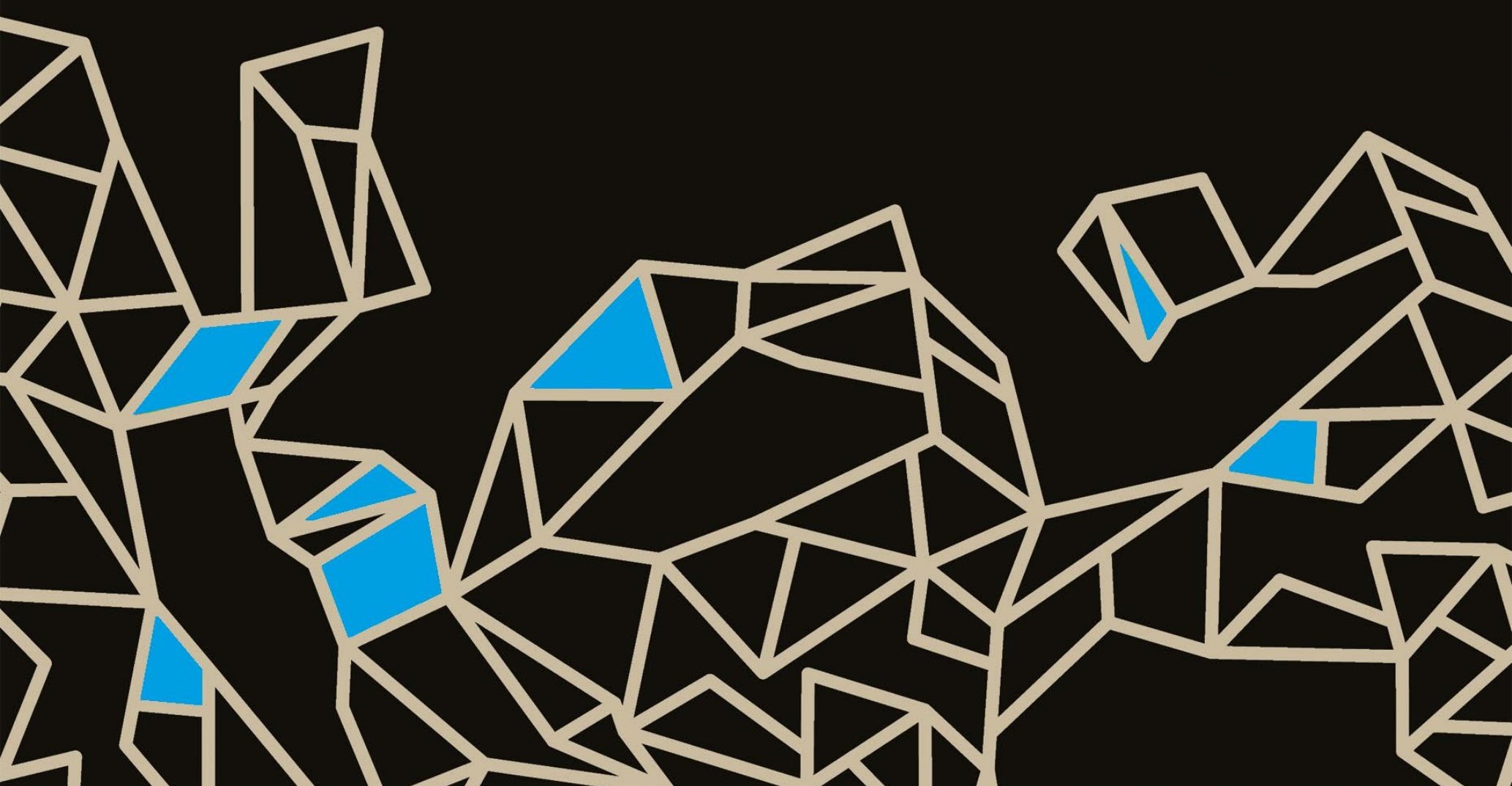


Em luta surda, cujos efeitos fogem ao próprio raio dos ciclos históricos, mas emocionante, para quem consegue lobrigá-la através dos séculos sem conto, entorpecida sempre pelos agentes adversos, mas tenaz, incoercível, num evolver seguro, a Terra, como um organismo, se transmuda por intuscepção, indiferente aos elementos que lhe tumultuam a face.

Euclides da Cunha, "A Terra", Os Sertões

Será que é possível fazer os que seguem entusiasmados com a globalização-menos entenderem que é normal, que é justo, que é indispensável querer conservar, manter, garantir o pertencimento a uma terra, a um lugar, a um solo, a uma comunidade, a um espaço, a um meio, a um modo de vida, a uma profissão, a uma habilidade? Reconhecer esse pertencimento é justamente o que nos mantém capazes de registrar mais diferen-

ças, mais pontos de vista e, sobretudo, de não reduzir sua quantidade.

Bruno Latour, Onde Aterrar?

O que estamos vivendo pode ser a obra de uma mãe amorosa que decidiu fazer o filho calar a boca pelo menos por um instante, Não porque não goste dele, mas por querer the ensinar alguma coisa. "Filho, silêncio." A terra está falando isso para a humanidade. E ela é tão maravilhosa que não dá uma ordem. Ela simplesmente está pedindo: "Silêncio". Esse é também o significado do recolhimento. Ailton Krenak, O Amanhã Não Está à Venda

Estratoporto, torre horizontal de lançamento para outros mundos terrenos. Por maior que seja a porta dupla, na maioria do tempo pintada de azul, embora uma ou outra peça possam ter o privilégio de fazer a cor mudar, e por mais vezes que tenha ganhado o valor de primeiro e único portal para dimensões desconhecidas, em tantas entradas e tantas saídas que marcam as passagens de cena nas encenações que ali se realizam, o pedestre desavisado passa, olha e não a vê. Um ou outro interrompe sua caminhada ligeira e breca. Se tivesse o impulso de entrar ali, haveria quem the realizasse o desejo prontamente, porteiras e porteiros que formam, com outros trabalhadores, uma história à parte: 60 anos de zeladoria. Na ponta da pista, o observador incauto tentaria compreender a visão fragmentada à sua frente, no claro-escuro de um túnel indecifrável. Se percorresse um pouco mais o declive nem tão suave por nada mais do que 25 longos passos, estaria no centro, pisando o tampo do buraco que abrigou tanto os últimos combatentes de Canudos quanto a pira de Zeus. Sendo alguém que saiba um pouco das 
coisas, o espaço o obrigaria a realizar um giro completo com o corpo, em que o olhar contemplasse não somente a tomada panorâmica à altura dos olhos, mas, em movimento de tilt, para cima e para baixo, toda a intensa verticalidade, somente equiparável à horizontalidade dos pontos de fuga definidos pela porta azul e, de frente para ela, um muro, um buraco, ou duas pequenas portas em arco, como passagens medievais. Mais do que a apreensão visual, entraria pelos buracos desse visitante imaginário a sensação que escorreu de uma realidade torcida num tempo e espaço imensuráveis, em que somente podem-se "escolher pontos e inventar soluções" (BO BARDI, 2018).

No ponto temporal demarcado pelo octogésimo ano do século $X X$, o ponto espacial era só a casca, três paredes definindo o perímetro alongado daquele lote típico do bairro do Bexiga, onde os negros formaram seus quilombos modernos para fugir da serventia dos brancos da alta sociedade capitalista, que viviam no espigão da Avenida Paulista. Depois os italianos ergueram casas comunais, riscando as plantas baixas dos cortiços o Navio Parado, no vale do Rio Bexiga, foi um dos maiores - diretamente no chão onde seriam construídos, para explorar com aluguéis baratos pagos por aqueles que precisavam permanecer próximos ao coração da cidade, conformando-se assim a principal periferia central de São Paulo e o umbigo cultural a ligar o país com seus antepassados no samba, na culinária, na vida comum das ruas e nos teatros.

Não havia teto no número 520 da Rua Jaceguay naquele momento e as ações de teatro que ali se realizavam a céu aberto mostram, em vídeos preciosos, que elas devem ter sido as grandes inspiradoras para que se mantivesse, depois, o contato direto com o céu, com o horizonte da cidade, com a paisagem que cerca o endereço.

Havia duas décadas que o Teatro Oficina se constituíra por estudantes na Faculdade de Direito do Largo São Francisco e ocupara aquele ponto, então um teatro espírita - o Teatro Novos Comediantes. A primeira comédia dos novatos foi encontrar o espaço pelado de seu equipamento interno, que eles imaginavam que seria deixado pelo antigo grupo. Aproveitaram para realizar a primeira arquitetura cênica pelas mãos do arquiteto Joaquim Guedes: palco central, duas plateias íngremes, em sanduíche, para acoIher maior número de público. Essa disposição cênica, que durou somente 
seis anos, foi o palco de obras que marcaram definitivamente a história do teatro, dentre elas Os Pequenos Burgueses, de Máximo Gorki. Quando em 1966 um incêndio, que se suspeita tenha sido criminoso, perpetrado por paramilitares, queimou as paredes e as arquibancadas, Guedes comemorou: "Caiu a Casa dos Pequenos Burgueses!" e o grupo tinha novo espaço para avançar em suas pesquisas cênicas.

Flávio Império e Rodrigo Lefévre projetaram a nova arquitetura, erguida em menos de um ano. Com palco giratório muito próximo à primeira fila de cadeiras e um corredor no meio da plateia, O Rei da Vela, de Oswald de Andrade, e principalmente Roda Viva, de Chico Buarque de Hollanda, quebrariam a quarta parede pela força de seus coros e não pelo distanciamento brechtiano. O público levantava-se das cadeiras durante as cenas e atores ocupavam toda a extensão da plateia. Junto à nova arquitetura cênica, já estava proposto um programa extenso: apresentação do repertório, ações de pesquisa e formação, cantina, cinema, espaços de convivência e outros que se pretendia erguer no entorno ou em algum outro local apropriado.

O Ato Institucional ํㅜ 5, decretado pelo presidente Costa e Silva em 13 de Dezembro de 1968, além de fechar todas as casas legislativas e extinguir todos os direitos políticos dos cidadãos brasileiros, decretava expressamente em seu artigo 5 a "proibição de frequentar determinados lugares" com o intuito de atingir diretamente os teatros. Tornou-se impossível seguir com os trabalhos e, assim como muitos outros artistas, o Oficina passou a viver em comunidade, morando no próprio teatro. Era uma comunidade multimídia, composta também por jornalistas que instalaram ali a redação clandestina do periódico $O$ Ex e saíam somente para fazer as apurações nos orelhões das calçadas, receosos das escutas em telefones fixos, depositando tubos de fichas nos aparelhos públicos quando as conversas se alongavam.

O teatro foi invadido pela Polícia Federal e, em 1974, o diretor Zé Celso e outros integrantes foram presos e torturados, obrigando-os ao exílio em Portugal, França, Moçambique e Inglaterra. Com o início da abertura do regime ditatorial brasileiro, a partir de 1978, o grupo voltou carregado com a experiência da Revolução dos Cravos e, inspirado por ela e por uma viagem de ácido em que desenharam uma mandala na parede do fundo e, ao apontarem o centro do desenho, viram-se transportados para o outro lado. Abriram 
assim as portas do Oficina para que ele fosse ocupado principalmente pelos imigrantes nordestinos e por um público diverso, que se reunia em noitadas de forró, de cabaré e de comida na cantina da alagoana Zuria. Tinha início uma nova engenharia de produção, a Uzyna Uzona, em trabalhos empíricos da ocupação de um Terreiro Eletrônico, para o que em muito colaborou o prêmio - televisores e uma câmera de vídeo da Sharp - recebido pelo filme Caderneta de Campo, vencedor do primeiro festival Videobrasil. O grupo açodava o prédio. Catherine Hirsch, que viera do exílio com o grupo, considerada, com justiça, diretora do diretor da Associação Teat(r)o Oficina Uzyna Uzona até os dias atuais, estava apaixonada pelo espaço e liderava as pequenas demolições internas que se iniciaram então.

Dois textos de Oswald de Andrade serviam de guia e base para os trabalhos: O Homem e o Cavalo, peça épica de 1934 na linha de Gropius e de Maiakovski, cujo argumento demole no entreguerras o idealismo remanescente do século XIX em cenários tão díspares e amplos quanto o céu, a Barca de São Pedro, o interior de uma estratonave e uma pista de corridas de cavalos; e Do Teatro que é Bom, crônica em que o autor lançara a ideia de um teatro para a paixão das multidões, como o futebol, um Teatro de Estádio, como o Oficina passou a chamar esse vislumbre.

No dia 30 de março de 1979, primeiro aniversário de Zé Celso depois da volta do exílio, o pedreiro Pompílio quebrou a primeira parede que separava o antigo palco da parte dos fundos do teatro e no dia $1^{\circ}$ de janeiro de 1980 ele quebrou a janela dos fundos, revelando a todos a topografia natural de um anfiteatro, onde poderia estar o Teatro de Estádio. No centro da cena, cobertas por frágeis telhados de zinco, em vez da Barca de São Pedro, kombis brancas do Baú da Felicidade, programa de sorteios e recompensas que distribuía utensílios domésticos àqueles que pagavam religiosamente em dia as folhas de um carnê parrudo, estavam estacionadas. O Baú da Felicidade era uma das principais atividades do tipo caça-níquel que o grupo empresarial de Silvio Santos, o camelô que se tornaria um dos homens mais ricos do Brasil, realizava e promoveria em rede nacional de televisão, a partir do ano seguinte, quando o último presidente da ditadura concederia ao grupo empresarial o Sistema Brasileiro de Televisão (SBT). Sob as kombis do Baú passava um rio, que com o Itororó e o Saracura, formam o 
Anhangabaú, na região atual da Praça da Bandeira. Todos três tampados, todos três escondidos, há quase cem anos.

Alguns meses depois, no mesmo 1981, o Grupo Silvio Santos (GSS), que já cercava o teatro com a posse de grande parte dos edifícios do entorno, tentou comprá-lo do então proprietário, o senhor Luiz Cocozza Sobrinho, que foi obrigado a oferecer a venda prioritariamente àqueles que o ocupavam há tanto tempo e pagavam o aluguel com a mesma diligência dos adeptos do Baú, sob a fiscalização severa da atriz Maria Alice Vergueiro. É certo que a compra fazia parte dos planos do grupo empresarial em obter a maior área possível no quarteirão, demolir tudo, e erguer um empreendimento que talvez não estivesse definido. De qualquer forma, ainda que um ou dois imóveis viessem a servir de depósito para os prêmios do Baú, todo o resto poderia ser, como seria, demolido, transformando-se de ativos a passivos perfeitos para a especulação imobiliária que os valorizaria em cálculo exponencial enquanto serviam de estacionamento, num verdadeiro processo de desertificação.

O Oficina correu atrás do dinheiro para a compra e a iminência do despejo fez com que artistas das mais diversas linguagens - entre eles, Caetano Veloso, Gilberto Gil, Tom Zé, o mestre cirandeiro Surubim Feliciano da Paixão e a forrozeira Sandy Celeste, a Billie Holiday do sertão - junto ao público e à companhia criassem um movimento de solidariedade, que cresceu ao ponto de arrecadar em shows beneficentes no Parque do Ibirapuera 1.250 .000 cruzeiros que, somados a 1.000 .000 provenientes de fundos públicos de cultura, serviriam de entrada para o financiamento de outros 6.750 .000 , somando o total de 9.000 .000 de cruzeiros. Os bancos, no entanto, não aceitaram, pois o Oficina não conseguia garantir, por óbvio, que honraria com as parcelas adiante. Não seria nessa ocasião que as instituições financeiras saberiam dar ou receber - o devido valor pecuniário dos trabalhos artísticos.

O Oficina então investiu parte do dinheiro arrecadado na compra de uma câmera de vídeo U-Matic, trazida da Flórida na bagagem de Fernando Meirelles, futuro cineasta de Cidade de Deus. O capitalismo videofinanceiro do SBT e do GSS teria ao lado o núcleo cinematográfico O Homem e o Cavalo, filmando praticamente todas as ações artísticas e investidas políticas, o que já era uma prática da companhia mesmo nos tempos da película. Graças a essa nova engenharia, que percebia este núcleo tecnológico 
e de comunicação como a ponta de lança do grupo, tornou-se mais fácil e fez-se possível ao público acompanhar, desde então, uma luta épica, muitas vezes mal compreendida.

O movimento desencadeado pela ameaça de desaparição ou desterro do Oficina causou, logo em seguida, em uma confluência com a entrada do geólogo Aziz Ab'Saber na presidência do Conselho de Defesa do Patrimônio Histórico, Arqueológico, Artístico e Turístico do Estado de São Paulo (Condephaat), o tombamento do teatro como bem material, o que, somado à subsequente desapropriação pelo estado de São Paulo, em 1983, garantiria a permanência do grupo no espaço.

O tombamento baseou-se em parecer de Flavio Império que defendia a necessidade de que o equipamento interno do Oficina não se congelasse e pudesse se transformar conforme os trabalhos que viriam. Essa noção, diante de procedimentos resultantes de um patrimonialismo arraigado em um país colonizado, era por si uma revolução. De lá para cá, muito se mudou e é de se supor que tenha havido uma importante contribuição da própria luta do Oficina para um avanço que se faz cada vez mais urgente. Os dispositivos dos órgãos de patrimônio são obsoletos, o tombamento incide somente sobre o bem material e apenas há poucos anos passou a ser possível fazer um registro de bens imateriais, sobre o qual incide uma proteção ainda menos definida do que aquela no Livro Histórico de Tombo. Ou seja, a imanência dos espaços criados e transformados pelo trabalho do teatro contemporâneo brasileiro simplesmente não existe para estas entidades, o material e o imaterial estão desassociados, como se isso fosse possível de conceber.

A inflexão que os anos 1980 significaram para o Oficina pode ser vista em quadro mais amplo. Ao mesmo tempo que as elites econômicas no mundo todo percebiam que seria impossível que o planeta sustentasse a realização completa do liberalismo global idealizado e começavam a preparar o engodo de 40 anos, misto de negacionismo e soerguimento de muros em que $1 \%$ da população garantisse para si o que tinha sido sonhado, o Oficina abria-se para o surgimento do terremoto que revolvia o solo da propriedade privada, desenhando seu novo espaço integrado ao máximo à cidade, forçando todos os limites impostos pela lógica do capital. Desde então, por 40 anos, o resultado do negacionismo e da atribuição do ônus pela elite 
obscurantista aos "outros" resultou na "extensão vertiginosa das desigualdades", como escreve Bruno Latour (2020). E, desde então, o Oficina luta nesta zona de fronteira entre o interno e o externo, procurando desfazer os limites com seu poderoso arsenal estético e funcionando como uma antena que nunca se desligou da realidade brasileira e mundial. Zé Celso atribui o papel de musa inspiradora a Silvio Santos, considerando a luta que calhou ao Oficina a salvaguarda de uma possível alienação. Mas o apresentador e os sucessivos projetos que seu grupo empresarial teriam para a região do Oficina são mais sintomas e joguetes de uma realidade que teria se imposto ao grupo, onde quer que ele estivesse.

O rio que estava sob as kombis do Baú é o Rio Bexiga, hoje o protagonista da luta. E não deixa de ser a marca de um destino que ele deva liquidar o embate e as fronteiras definidas pelo indígena come-cabeças, a Rua Jaceguai, onde está a porta azul e o branco italiano que andou sobre as águas para salvar seu primo Plácido do afogamento, a rua Santo Amaro, no nível mais alto dos terrenos do entorno e a Rua da Abolição, essa que, depois de uma luta também épica e também longa, negras e negros brasileiros estão conseguindo fazer ver ao resto da população que é preciso completar.

Com o tombamento, a desapropriação, o Terreiro Eletrônico em funcionamento e a visada para a abertura da cena no espaço do anfiteatro ao ar livre no estacionamento do Baú, era necessário um novo projeto arquitetônico. Foi este projeto que Lina Bo Bardi então desenhou, ao lado de Marcelo Suzuki e Edson Elito, e que seria realizado parcialmente, delimitado ao espaço já ocupado, mas aberto ao entorno. "Galerias da Ópera de Milão dando para as catacumbas de Silvio Santos", como previa Lina Bardi. As galerias lá estão. As catacumbas seriam, a partir dali reinventadas, ocupadas e desocupadas, inúmeras vezes, em um movimento repleto de significados, dos quais apenas alguns caberão neste texto.

Lina acompanhava de perto o Oficina desde o tombamento, quando insistiu para que o Condephaat, de alguma forma, propiciasse também a desapropriação dos terrenos do GSS. Ela fez então uma série de desenhos para o espaço, certamente inspirada por um projeto que já havia apresentado para o vale do Anhangabaú, anos antes. Assim concebeu a 
pista de passagem, "teatro pé na estrada", que se tornaria o novo Oficina. Elito transformou aquelas ideias e aquarelas em projeto técnico executivo, a ter sua construção iniciada em 1987 e completada depois da morte da arquiteta. Note-se que o segundo Oficina, desenhado por Flávio Império, levou menos de um ano para ser construído após o incêndio do primeiro, em 1966 e este, o terceiro, sob a ditadura civil-militar, levaria mais de uma década. Em 1993, o novo Oficina abria as portas azuis da Jaceguai, com Ham-let para receber o público. Estava praticamente terminada a obra e configurado o espaço que seria ocupado em permanente tensionamento de seus limites: à frente, paralelo a Rua Jaceguai, um trecho do que os paulistanos chamam popularmente de Minhocão, via expressa para carros construída no auge da ditadura e símbolo da urbanização corrupta e desastrosa que sempre assolou São Paulo; na lateral direita, dividindo paredes, um prédio residencial cujos moradores reagem ao barulho das encenações com o lançamento de ovos à pista nos momentos em que o teto retrátil abre o teatro para 0 céu da cidade; na lateral esquerda, um enorme janelão, atravessado pela árvore Cezalpina que Lina plantou e que avança sobre os terrenos do GSS. Ao fundo, afinal, o beco, o cul-de-sac, onde circularam como feras enjauladas as ideias para um cu que desate, uma abertura que se faça, análoga à porta principal, diante dela 50 metros à frente e permita que desça ao vale o que as tripas processam.

A nova arquitetura cênica estreou com Ham-let, em 1992. Um pouco antes, o arquiteto Paulo Mendes da Rocha, prêmio Pritzker de 2006, arriscou, a pedido de Zé Celso para uma apresentação pública nos 101 anos de Oswald de Andrade no dia 11 de janeiro, desenhar uma possibilidade de expansão da arquitetura cênica, contemplando o Teatro de Estádio ao fundo. Essa era a maior novidade da proposta, que ocupava também terrenos públicos, vestígios da implantação do Minhocão, com uma Torre da Memória para abrigar diversos acervos de companhias de teatro e um outro edifício para a administração do Oficina. No térreo deste, o arquiteto esboçou ainda um bar, na longa tradição dos bares que funcionam em teatros ou próximo a eles, onde o público pudesse ir, nas palavras de Mendes da Rocha, "ao que interessa". No programa e no projeto, havia ainda uma ágora, nos baixios do viaduto, onde os habitantes do bairro pudessem se encontrar. 
Talvez tenha sido esse o primeiro gesto projetivo que extrapolou os limites do lote já ocupado e dos terrenos pertencentes ao Grupo Silvio Santos, no sentido de buscar a vida pública do bairro e da cidade.

Em março do ano 2000, recém saídos da ameaça do bug do milênio e no primeiro ano de um século que parece ainda não ter se iniciado de fato, enquanto o grupo ensaiava Boca de Ouro, de Nelson Rodrigues, soube-se através da imprensa que o Grupo Silvio Santos havia conseguido autorização do Condephaat para erguer nos terrenos envoltórios um horrendo shopping center, projetado pelo arquiteto Júlio Neves, com o significativo nome de "Bela Vista Festival Center.' A proposta era assustadora não somente porque tratava-se de mais um shopping para a cidade, ignorando completamente as necessidades e realidade do bairro, mas também porque via-se o propósito de ignorar a existência do Oficina e sua relação de abertura e tensionamento dos limites com o entorno, transformando-o no que à época foi considerado pelo grupo, ingenuamente generoso, em uma casa de cachorro da grande propriedade. Estava patente que, embora não tivesse conseguido comprar e demolir o teatro em 1980, vinte anos depois o grupo ainda o faria se não tivesse então de enfrentar os órgãos de proteção do patrimônio. Vale dizer que o Oficina havia sido tombado também em esfera municipal, em 1991, pelo Conselho Municipal de Preservação do Patrimônio Histórico e Ambiental da Cidade de São Paulo (Conpresp).

Estava de novo o Oficina erigido como a grande pedra no caminho a ser devastado pelos intuitos lucrativos do GSS.

A luta, travada em três frentes, ficaria mais intensa a partir dali. As obras encenadas pelo Oficina trariam a realidade desta luta amalgamada à dramaturgia; além disso, seria discutido, em diferentes fóruns, e em grande parte com a mediação de mais de um Ministério Público (MP), o que significa ser tombado como patrimônio material e registrado como patrimônio imaterial para a proteção do bem imóvel e do trabalho que se realiza no endereço; e se buscaria o diálogo com o GSS para confrontar projetos para a área. Neste último campo, estariam frente a frente concepções de urbanização e de estética que se mostrariam, na maioria das vezes, antagônicas. Nessas horas, a propriedade privada falava mais alto e algumas performances da Oficina Uzyna Uzona se faziam necessárias a fim de mostrar uma tenacidade e um arrojo que surpreenderia os executivos do GSS. 
Em 30 de março de 2001, a equipe que realizava oficinas de direção de arte para os movimentos iniciais de criação de Os Sertões, dirigida por Laura Vinci, fez da primeira parte da obra, "A Terra”, uma encenação laboratorial com a participação dos atores, na qual se encadeavam ações propositivas para soluções cenográficas e se narrava com roteiro próprio o primeiro capítulo do livro de Euclides da Cunha, que era lido desde o ano anterior por um grupo de mais de cem pessoas em coro. Ao final desta encenação, o coro de cenógrafos e atores fez de um tubo metálico, aríete e empunhou marretas para abrir em pancadas coletivas o primeiro buraco dessa nova fase do beco. A primeira personagem a atravessar o buraco foi um militar do exército republicano, em "A Luta", que despencou sem querer alguns metros para baixo, no estacionamento, quebrando as telhas que protegiam os carros. Ressurgiu vivo e inteiro na porta da frente do teatro, tendo realizado a primeira volta completa.

A Sisan, braço imobiliário do GSS, intensificou no início dos anos 2000, a compra e demolição dos edifícios da quadra. Foram sendo derrubadas, uma a uma, as casas. Do janelão, observava-se o cenário de guerra que se conformava, ao mesmo tempo em que se expandia a dimensão da potencial ocupação da cena ao ar livre e começava a se afirmar, para o Oficina e para os urbanistas que se envolviam com a questão, a importância de se manter integralmente o vazio que se revelava no vale do rio, onde poderiam coexistir as ações de teatro com um novo espaço de convívio.

O buraco do beco fora fechado algumas vezes pela Sisan, e foi sempre reaberto pelo Oficina. Era um elemento de contracenação privilegiado, por onde eram passados bilhetes para o vizinho antagonista pedindo um gesto de grandeza e generosidade com a cidade, a doação da área para implementação dos projetos do Oficina. A saga de Os Sertões se completou com cinco peças, tendo como inspiração e material de trabalho a disputa de território, em muito identificada com a luta de Canudos. A imagem símbolo de "A Terra", impressa nos primeiros programas, ainda em 2002, era o buraco do beco, recém aberto. Quando a última peça, $A$ Luta II, estava pronta, o GSS havia decidido que era hora de fechar definitivamente o buraco e usou restos da demolição da primeira sinagoga de São Paulo, que funcionava na Rua Abolição, para tapar o buraco com uma parede espessa de concreto. Entre os detritos reutilizados, estava uma grande estrela de Davi intacta, 
trançada com chapas metálicas, que a personagem de Antônio Conselheiro passou a usar como colar ao guiar o público, ao final de "A Terra", para que estampasse de verde a parede do beco, como líquens que atacam gentilmente a pedra com suas mãos.

O fato de nunca ter se chegado ao ponto de estabelecer definições sobre a gestão dos diferentes projetos que o Oficina e arquitetas e arquitetos que o orbitavam passariam a propor e o fato de terem sido tantos e tão diferentes projetos foram muitas vezes usado como argumento para demonstrar uma suposta falta de objetividade nas contrapropostas do teatro. Na verdade, isso significa, de fato, bem o contrário: há uma miríade de possibilidades para a arquitetura cênica, para a configuração urbana e para a administração dos espaços que viessem a ser criados, e nenhuma delas poderia ser descartada ao longo de um processo de luta. Essas ideias se acumularam, se chocaram e amadureceram os propósitos, ao ponto de haver hoje, certamente, um dos maiores conjuntos de estudos e possibilidades para que o destino de um território de São Paulo, devastado pela iniciativa privada, possa ser de usufruto público, desde que haja medidas de órgãos públicos acolhendo esse imenso trabalho já realizado.

A Procuradoria do Meio Ambiente instaurou inquérito civil para apurar a aprovação preliminar concedida pelo órgão estadual de defesa do patrimônio estadual em 2000, além de mediar diversas conversas entre o Oficina e o grupo empresarial. Desde o início, a companhia passou a pleitear a presença do próprio Silvio Santos nas discussões. No final do ano 2000, foram apresentadas, no âmbito dessas discussões, duas propostas para a construção de ao menos parte do programa do Oficina, uma delas das arquitetas Cristiane Cortilio e Celia da Rocha Paes e outra de Edson Elito, ambas recusadas pelo GSS.

Enquanto Elito propunha o espaço do Teatro de Estádio ao fundo, como bacia em que desaguaria a pista do Oficina, cercada por ruas de pedestres que viabilizariam o atravessamento de todo o conjunto a pé, ressuscitando antigas vias, Célia e Cris reajustavam os vetores e faziam da pista, aberta na lateral do janelão e da árvore Cesalpina, uma skené, tendo à frente o palco para a orquestra, apropriando-se da conformação grega em uma topografia que realmente parece ajustada a ela. Estava projetado também o 
erguimento de dois edifícios para abrigar as atividades complementares de formação, pesquisa e acervo que já constavam no programa. Dois anos depois, Cris desenvolveria ainda mais a proposta em trabalho de conclusão do curso de Arquitetura na FAU-USP, orientado por Ângelo Bucci.

No início de 2001, o Oficina soube que o projeto do GSS estava definitivamente aprovado, com assinatura do então prefeito, Celso Pitta, em seu penúltimo dia de mandato. Quando novamente as duas partes se encontraram, ao final de março daquele ano, fechou-se o diálogo e o caso no MP também seria encerrado. Havia aí um primeiro sinal da falta de transparência com que o grupo empresarial travava as discussões e da postura insidiosa com que pretendiam levar o assunto a termo. O Oficina passou a conclamar a presença de Silvio Santos, apelando para sua sensibilidade de artista e de comunicador para que o diálogo fosse retomado. Julio Neves ainda apresentou a Zé Celso, em encontro reservado, uma contraproposta para a construção de uma arena similar àquela que Mendes da Rocha havia esboçado, mas na Rua Japurá, mais além dos terrenos já pertencente ao GSS, afirmando que poderiam comprar e demolir os sobrados daquela rua e criar uma travessia subterrânea entre a pista do Oficina e essa nova área, o que foi prontamente negado pelo diretor do teatro, antigo morador de um daqueles sobrados.

Este embate, chamado por maus observadores de "novela", "pendenga", "querela" e outros termos que diminuem seu real significado, teve lances admiráveis. Com o mergulho da companhia nos trabalhos de realização de Os Sertões, um projeto antigo, ficou ainda mais claro que a definição daquela terra como o lugar em que homens e mulheres deveriam encampar sua luta de sobrevivência era inevitável. Por iniciativa de alguns integrantes do Oficina associados a uma importante figura oriunda da escola de samba Vai-Vai, o capoeirista Pedro Epifânio, criou-se o Movimento Bexigão, que reunia as crianças do bairro no teatro para aprenderem em diversas instâncias da produção teatral, da música à comunicação digital, passando pela atuação e atividades corporais. O Bexigão se tornou rapidamente também um coro das peças e chegou a excursionar com Os Sertões para a Alemanha, abrindo a temporada do outono de 2006 do Volksbühne, em Berlim.

O Bexigão e uma política de descontos nos ingressos das peças para os moradores locais fortaleceu a relação do Oficina com o bairro; no entanto, 
sempre houve grande dificuldade em convencer os moradores dos arredores e mesmo o cidadão comum, e de bem, que haveria maior benefício na criação de espaços culturais e de convivência do que na construção de mais um shopping na cidade. Além disso, o GSS havia se apropriado do termo "cultura" e vendia ao bairro um "shopping cultural", bem ao modo da "Broadway brasileira" com que certas classes procuram identificar não o Bexiga, mas a "Bela Vista".

Um argumento, que há muito observamos nas soluções brasileiras, também ecoava: "já está degradado, pior não vai ficar", sem que houvesse atenção para o fato de que os principais responsáveis por aquela situação eram justamente aqueles que agora surgiam como "revitalizadores." Por isso, à época, era importante para os que lutavam com o Oficina chamar o que se pretendia de "revivescência" e não de "revitalização". A vida do bairro estava intacta, ainda que soterrada. Não havia morte, mas encobrimento. A solução não viria com a gentrificação, com a definitiva expulsão dos moradores mais pobres, mas sim com uma guinada nos vetores de referência sobre o que é necessário fazer pela sobrevivência do planeta. Hoje, à distância de duas décadas, não parece exagero afirmar que a luta do Oficina contribuiu muito para que o atraso da tomada de consciência ecológica não fosse ainda maior.

"A Terra", primeira parte d'Os Sertões, estreou em 2 de dezembro de 2002, aos cem anos da publicação do livro de Euclides da Cunha e depois de uma série de ensaios abertos ao público. Estes ensaios tinham propiciado a inclusão do público no coro dos estratos geológicos, rios, mares, bichos, que dançavam e cantavam a narrativa épica que Euclides criou para, em um voo de águia sobre o Brasil, chegar, afinal, em Canudos, na Bahia, território a se fundir no espaço e no tempo com o quadrante do Bexiga. Esses coros remontam ao outro cruzamento temporal desta história, o final da década de 1970 e início de 1980, quando a ideia da dissolução do palco e da plateia impulsionava as aberturas da arquitetura cênica que se desenhava. Ligando os dois pontos, o Oficina tinha a realização coreográfica, mas ainda precisava escapar da estreiteza da pista que espremia Os Sertões.

Em 2004, por intermédio do então senador Eduardo Suplicy e do psicanalista Contardo Calligaris, que publicou uma carta aberta a Silvio Santos na Folha de S.Paulo "como se fosse a carta de uma criança que the pede ajuda para que nosso melhor circo continue e cresça", o apresentador finalmente foi 
ao Oficina para uma visita. Este evento de "serendipity", uma grata e inesperada surpresa como o etiquetou o senador, foi tão importante naquele momento Zé Celso o via como uma possível revolução na cultura de São Paulo - quanto se mostraria ilusório em triste episódio recente. A cara de cera do apresentador televisivo desceu de um carrão preto que estacionou próximo à entrada do teatro e caminhou decidida em direção à porta azul da esperança, que uma atriz gentilmente abriu para ela. Dentro, em roda, o coro d'Os Sertões, quase surpreendido porque não houve antessala para a presença, disparou a cantar uma Ave Maria e as luzes do teatro brilharam enchendo de dourado o espaço que o vizinho de três décadas adentrava pela primeira vez. Silvio levou algum tempo para entender que estava dentro de uma cena dedicada ao poder de sua presença e procurava responder às palavras cantadas pelos atores até que recebeu das mãos de Zé Celso um exemplar de Os Sertões, foi carinhosamente abraçado pelo diretor e parabenizou o grupo com palavras do tipo "se vocês representam tão bem assim quanto cantam, estão de parabéns...." Chegaram Eduardo Suplicy e seu filho Supla e juntaram-se ao grupo, que passou a realizar um tour em que o apresentador descobria espantado a dimensão e as perspectivas da "terra ignota" enquanto ouvia do diretor do Oficina as propostas para a expansão arquitetônica e ocupação de suas propriedades pela companhia. Era um programa amplo, definido a partir de diferentes projetos, a que outros ainda viriam juntar-se. A abertura de fé a um diálogo com o grande parceiro em potencial inspirava as palavras do diretor e a cena se assemelhou àquela em que padres em missão de persuasão foram guiados por Canudos e conheceram as obras da igreja nova que se erguia para ao fim sugerir a dispersão da comunidade. Mas, ao contrário, Silvio Santos se despediu prometendo levar as propostas do Oficina a Sisan e, mais importante, deixou a impressão de que agora o "artista" Silvio Santos tomara pé da realidade e das pretensões do antigo vizinho.

Em pouco tempo, o GSS contratou o escritório Brasil Arquitetura (BA) para elaborar novo projeto. A Brasil Arquitetura tem entre os sócios Marcelo Ferraz, que trabalhou durante 15 anos com Lina Bo Bardi e é considerado um de seus discípulos. A proximidade estética e a disponibilidade aberta pelo escritório para receber o programa com que o Oficina trabalhava naquele momento - o que aconteceu em uma única reunião no escritório da BA - 
pareceu alvissareira para o teatro. No entanto, dois ou três meses depois, o projeto foi apresentado pelos arquitetos no Oficina e contemplava somente o programa da Sisan, a não ser por um teatro confinado no miolo de galerias de um shopping que o escritório insistia em comparar ao Conjunto Nacional, na Avenida Paulista, como exemplo de bom urbanismo. Ao final da apresentação, era necessário que o Oficina decidisse se aceitava que o projeto pegasse carona no trâmite de aprovação já encaminhado nos órgãos públicos de patrimônio e obras. Contardo Calligaris estava presente, chamou Zé Celso a um canto e disse: "eu fui sindicalista, sei quando é a hora de ceder, e essa hora chegou". O Oficina aceitou que o projeto seguisse os trâmites burocráticos, mas ficou também o acordo de que novas rodadas de discussão seriam realizadas, para ajustar a proposta. Por fim, os próprios órgãos de defesa do patrimônio pediram alterações substanciais, já que o edifício projetado virava as costas para o quarteirão e ao final, em 2007, a construção foi judicialmente impedida.

2005 foi um ano de muita demolição. Entre elas, a da sinagoga que forneceu o material para o fechamento intransponível do buraco do beco, compondo a instalação que o Oficina passou a chamar de Auschwitz. Foi natural que a mira das ponteiras e dos martelos passasse então à parede lateral, sob o janelão, por onde passa a Cesalpina. Um outro buraco passou a ser aberto ali, em cena, quando os canudenses faziam o furo inaugural da Igreja Nova, templo e bunker que garantiu os dias finais da resistência de Canudos. Também o janelão, num esforço de cenografia e de arquitetura cênica criadas por Osvaldo Gabrieli para as duas partes de "O Homem" de Os Sertões, foi aberto em diversos quadrantes nos quais, a partir de plataformas de metal, era possível acessar o espaço aéreo do terreno lateral, que ainda servia como estacionamento, mas agora explorado por terceiros. A encenação de Os Sertões forçava ainda mais os limites das paredes e se apontava, com insistência, para o entorno do teatro como o vale do rio Vaza Barris, que circundava Canudos. Fogos de artifício explodiam sobre o estacionamento ao lado quando o meteorito Bendegó caía no centro da pista, primeiro evento a atrair os olhares dos forasteiros para o sertão baiano; um coro de canudenses abrigava-se nas plataformas entrelaçadas pelos galhos da Cesalpina para celebrar, em missa profana, atores 
e público nus, um éden que fornecia tutti-frutti da consciência nietzschiana, além do bem e do mal; e um belo cavalo branco trazia da rua para a pista o Marechal Deodoro para dar o golpe que extirparia o "amor" da bandeira nacional, na proclamação da República.

Enquanto o Oficina levava Os Sertões, com suas cinco partes completas em mais de 24 horas de teatro, para Canudos, em 2007, apresentando a obra total em uma tenda no estádio municipal da cidade para 2000 pessoas, a Sisan convertia seu projeto em um condomínio residencial de três torres, com cem metros de altura cada e mais de 5000 apartamentos. Para além da pesquisa de mercado que pode ter orientado essa guinada, desde então o combate a esse projeto tornou-se mais difícil nos meios jurídicos.

O desfecho dos trabalhos de Os Sertões, que incluíram ainda a realização de cinco filmes a partir das peças, coincidiu com o cinquentenário do Oficina em 2008. Naquele ano, a companhia realizou o conjunto impressionante de seis peças ao mesmo tempo. Foram elas Vento Forte para um Papagaio Subir, de Zé Celso, encenada em 30 de março, dia de seu aniversário de 71 anos; Taniko, o Rito do Mar, pelo centenário da imigração japonesa no Brasil; Cypriano e Chan-ta-lan, de Luis Antônio Martinez Corrêa, que estava em cartaz desde o ano anterior; o Bori Atropofágico, no Sesc Avenida Paulista, primeira encenação do "Manifesto Antropófago"; Os Bandidos, de Schiller, que fez temporada até o final do ano; e, finalmente, o rito de encenação chamado Labrynco Oficina 50, este sim para comemorar especialmente o jubileu de ouro no dia 28 de outubro. 0 Labrynco durou em torno de 7 horas e foi um pot-pourri de todas as obras da companhia, com figurinos e adereços recriados a partir da impressionante memória de Zé Celso, em um "rito-rave-cyber-teatral" que mereceu ter seu registro em vídeo disponibilizado ao público na TV Uzyna. Essa profusão revelava, em grande parte, o potencial de criação que talvez tenha se represado nos sete anos de dedicação total a Os Sertões e seria, de toda forma, impulsionadora de um movimento de expansão que aconteceria a partir de 2010 quando, para surpresa de todos, a companhia teria permissão para ocupar os terrenos envoltórios.

Em 2009, consolida-se um programa-manifesto para o que desejava o Oficina à época: criar, a partir da ocupação de seu entorno, a Universidade 
Antropófaga, conjunto de ações formativas que abriria regularmente as atividades da companhia à participação de interessados em compor elenco e equipe técnica; a Ágora do Bexiga, lugar de encontro da companhia com os moradores do bairro para tratar das necessidades de seus habitantes; a Oficina de Florestas, que mantivesse a vegetação já presente nos terrenos e ainda os reflorestasse; e, por fim, o Teatro de Estádio. A esse programa estava dado o nome de AnhagaBaú da Feliz Cidade, apropriando-se do sentido caça-níquel do Baú e o invertendo. Apesar da morosidade com que seguia o diálogo, ainda era uma aposta da companhia que a parceria se concluísse em bom termo.

Três projetos arquitetônicos partiram deste programa, elaborados no curto espaço de tempo entre 2010 e 2012. Eles têm o valor de demonstrar a diversidade de partidos e perspectivas possíveis a partir dos desejos sempre móveis da companhia.

Jeremy Galvan (2017), à época um estudante de arquitetura da faculdade francesa Paris La Villete que cursava intercâmbio na Faculdade de Arquitetura e Urbanismo da Universidade de São Paulo (FAU-USP), deu início ao que viria ser o seu projeto de conclusão do curso, observando a viva interação dos moradores do Bexiga nas ruas onde moram e os cuidados que dispensam a elas, às calçadas e ao espaço comum. Ele pretendeu que essas características pudessem estar presentes na ocupação do Oficina e o resultado de seu trabalho abandonava certa monumentalidade que a própria concepção oswaldiana para o Teatro de Estádio carregava de Léger, Meyerhold, Gropius e Rodchenko.

Abraçando, com construções em escala próxima às das casas-tipo do bairro a escala maior do vazio conformado pela topografia natural, de acordo com o que ele chamou de "dupla escala do lugar", e tendo o prédio do Oficina novamente funcionando como uma skené atravessada nas pontas por galerias idênticas as já existentes no interior e que se estenderiam para abrigar o público e para ligar o edifício às novas construções que abrigariam ateliês. Este projeto trazia as primeiras ideias de uma concepção modular, leve e móvel, criando espaços de convivência nos interstícios.

O projeto cita Le Corbusier, em uma carta que o arquiteto enviara ao ministro Capanema, quando fazia projetos para o Brasil: "Senhor Ministro, não construa mais teatros com palco e plateia, deixe as praças, as ruas, 
o verde, livres, só construa plataformas de madeira abertas ao público e o povo brasileiro as ocupará, improvisando com toda sua elegância natural e sua inteligência".

Em sentido contrário, o escritório de João Batista Martinez Corrêa (JBMC ARQUITETURA \& URBANISMO, 2011), irmão de Zé Celso, coordenado por João e por sua filha Beatriz Pimenta, elaboraria no ano seguinte um projeto de grande impacto visual e monumentalidade, principalmente devido à cúpula do Teatro de Estádio, embora de estrutura permeável e curva, inspirada na topografia de Canudos a partir do mesmo programa. Este projeto, que ganharia um prêmio na Quadrienal de Praga, ocupava área maior e distinta daquela prevista no projeto de Galvan, mas ambos se mantinham no lote formado peIos terrenos adjuntos ao Oficina pertencentes ao Grupo Silvio Santos.

No ano seguinte, em resposta ao projeto de JBMC, Guilherme Pianca (2012) realizou, também como trabalho de conclusão de curso da FAUUSP, nova proposta para o Anhangabaú da FelizCidade com orientação do urbanista Alexandre Delijaicov, que há anos se dedicava à pesquisa e revivescência da malha fluvial de São Paulo. O projeto de Pianca parte da hidrografia - os três córregos tributários do Anhangabaú - e do relevo específico que define o "umbigo do Bexiga" no limite do lote, ao final da rua Japurá, para implantar sobre o vale edificações que têm o Teatro de Estádio como elemento central. Outras premissas do partido são a manutenção da visibilidade do Oficina de Lina Bardi e a franca abertura ao bairro dos vazios já estabelecidos, que ganhariam a configuração de uma grande praça. O mais surpreendente é a proposta de escavação dos terrenos, trabalho que necessariamente se iniciaria no campo da arqueologia urbana, para devolver à área as características geográficas originais e criar o subsolo onde se implantaria o Teatro de Estádio, em uma "praça-sombra", contraposta, mas ligada, à "praça-luz", já citada. Isto resolveria uma contradição fundamental dos propósitos do Oficina: ser um terreiro onde se praticam mistérios que não devem ser guardados em segredo. Este projeto foi muito inspirado por algo extraordinário que aconteceu dois anos antes, em 2010.

Naquele ano, o Oficina excursionou por oito capitais de estados brasileiros, apresentando quatro peças de seu repertório em teatros montados em tendas que abrigavam em torno de 2000 pessoas por sessão. 
As tendas eram montadas em praças públicas, geralmente lugares simbólicos, como a Praça XI no Rio de Janeiro, nascedouro do Samba, ou o próprio Eixo Monumental em Brasília, onde a turnê estreou, ou ainda em locais periféricos, como Peixinhos, em Recife ou a Barragem Santa Lúcia, em Belo Horizonte, com a expectativa de receber público diverso. Junto com as apresentações, havia oficinas, coordenadas pelos integrantes da companhia, sobre diversas instâncias da produção de teatro, que recebiam inscrições do público local interessado e se realizavam em outros espaços enquanto a tenda era montada. Esse longo trabalho, fruto de um convênio direto com o Ministério da Cultura, seu principal financiador, fez com que o grupo não somente conhecesse as reais possibilidades das encenações em grande escala, mas aprendesse a produzir aquelas ocupações e retornasse, ao final do ano, a São Paulo, pronto para ocupar os terrenos envoltórios do Oficina.

Em finais de junho, o Instituto do Patrimônio Histórico e Artístico Nacional (IPHAN) tombou o Teatro Oficina, completando a devida proteção nas três esferas de estado: municipal, estadual e federal. No parecer da conselheira Jurema Machado, que embasou o tombamento, pode-se encontrar uma corajosa defesa do atravessamento dos limites entre material e imaterial. Ainda que juridicamente o tombamento dê-se sobre o patrimônio material, de que forma é possível estabelecer a intervenção e a proteção necessárias quando ele se transforma de acordo com o patrimônio imaterial que ali se cria, estabelecendo verdadeiramente uma "arquitetura viva"? Se os órgãos de patrimônio são os meios pelos quais o Estado pode interferir na propriedade privada - que ocupa uma posição inapropriadamente sagrada na Constituição brasileira, fruto de um patrimonialismo sanguinário e perpetuador de misérias que nunca sofreu as ameaças de regulamentações previstas na carta de 88 -, como a função social da propriedade privada, por que não haveria a possibilidade de limitar a destruição dessa arquitetura viva perpetrada pelo mercado especulativo?

Havia, entre os conselheiros do IPHAN, a defesa de que houvesse somente o registro do teatro como bem imaterial, sem o registro no Livro de Tombo Histórico; no entanto, os argumentos da parecerista justamente levam ao tombamento de um bem material resultado do trabalho imaterial, como outro conselheiro, Dalmo Vieira Filho, havia argumentado anteriormente, 
tomando como antecedentes, não coincidentemente, o tombamento do terreiro de Candomblé Casa Branca, em Salvador, e do Estádio do Maracanã, no Rio de Janeiro. Nas palavras de Jurema:

Nesse aspecto, o que distingue o Oficina de todos eles [outros teatros antigos da região] é a continuidade. Não a longevidade, o que já seria muito, mas a permanência com renovação, permanência lastreada no vínculo com o presente, com o lugar, com a Terra - como em Canudos e com a cidade. E nisso o edifício e sua inserção explicam muita coisa; são, ao mesmo tempo causa e consequência.

Ai estaria, também em parte, a razão do tema ter motivado o debate interno ao IPHAN sobre um eventual Registro do Teatro Oficina como patrimônio imaterial, provavelmente na categoria de Lugar, debate de forma alguma desprovido de sentido, mas que não encontra coerência com o previsto no Decreto $3551 / 2000$, nem com as políticas e critérios que vem sendo adotados pelo DPI.

As considerações, presentes no dossier, sobre possível Registro do Oficina como Bem Imaterial tem, certamente, um lastro na constatação desse fenômeno, ou seja, de um espaço que somente se realiza mediante a ação, profundamente enraizado em um território que é São Paulo e que é o Bexiga e, sobretudo, de um espaço conformado pela imaterialidade da prática teatral. (ANHANGABAUDAFELIZCIDADE, 2012)

$\mathrm{Na}$ conclusão de seu texto, Jurema ainda elenca entre as decisões finais aquela

pela manifestação, ao Ministro da Cultura, de que o Ministério e o governo federal identifiquem mecanismos que viabilizem a destinação do terreno contiguo ao Teatro Oficina para um equipamento cultural de uso público, utilizando mecanismos tais como a aquisição, a desapropriação ou a conjugação destes com instrumentos urbanísticos a serem identificados em cooperação com o Município e com o Estado de São Paulo. (Ibid.)

Em um telefonema entre Zé Celso e Silvio Santos, logo após o tombamento, o apresentador aceitou o pedido do diretor para uma ocupação dos terrenos e as obras começaram em seguida, definindo o início de uma nova fase da disputa. Abriram-se integralmente os dois arcos do cu-desate e instalaram-se ali portas de vidro. Uma passarela improvisada passou a ligar a 
pista aos terrenos mais baixos e armou-se a tenda das Dionisíacas para realizar as mesmas quatro peças que haviam excursionado pelo Brasil: Taniko, Bacantes, Banquete e Cacilda!!. Instalou-se ainda uma cantina, também em tenda, e assim deu-se início à uma ocupação exemplar, que duraria três anos. Depois das Dionisíacas, no ano seguinte, em 2011, a Macumba Antropófaga estreou com o principal objetivo de impulsionar a troca do terreno entre os entes públicos e o GSS, como solicitado no tombamento pelo IPHAN.

A encenação, uma transcrição da íntegra do "Manifesto Antropófago", de Oswald de Andrade, tinha início na porta azul do Oficina, mas, em vez do público entrar por ela, ele era levado a uma volta pelas redondezas e presenciava cenas em algumas estações definidas: 0 antigo prédio onde morou Oswald de Andrade, o Teatro Brasileiro de Comédia e a Casa de Dona Yayá. Esta primeira parte itinerante durava cerca de uma hora e demandava enorme domínio do teatro de rua e da intervenção urbana. De volta ao teatro, o público seguia para uma grande oca de tecido e bambus erguida no terreno, o restaurante Troca-Troca, onde as personagens de Tarsila do Amaral e Oswald de Andrade, ao comer rãs, descobriam a Antropofagia. Em seguida, o público era direcionado à pista e galerias do Oficina de Lina, entrando, pela primeira vez, pelas duas portas abertas no antigo beco sem saída. Depois da peça, o restaurante Troca-Troca se transformava em cantina, onde público e artistas podiam comer e beber muito bem e estendiam a duração da noite em conversas e danças.

No meio do enorme vazio, amontoava-se, alto, o entulho de demolições realizadas pela Sisan. A esse montulho, o Oficina atribuiu nome e valor: o Sambaqui, que passou a ser o totem de uma percepção dos terrenos por sua importância natural e geológica que demandam trabalho de arqueologia. Demarcaram-se os portais das Ruas Abolição, Santo Amaro, Japurá e Jaceguai, ampliando agora o tensionamento dos limites para a área fora dos lotes, ou seja, o bairro. Um resto exuberante de vegetação que as demolições tinham deixado intacto, próximo aos fundos do Oficina, passaram a ser estudados e cuidados, assim como novas plantações foram realizadas, tanto no Sambaqui quanto no seu entorno.

Mesmo com essa ocupação exemplar, a troca entre terrenos não saía, muito por ausência do grupo nas negociações tentadas com a ministra da 
cultura à época, Marta Suplicy. Os órgãos de defesa foram aprovando a construção das torres residenciais do GSS, ainda que em 2014 tenha havido o registro do teatro como bem imaterial no Conpresp, o órgão municipal do patrimônio. Este ainda é o maior empecilho para as intenções do empreendimento imobiliário. Em 2012, numa coincidência infeliz, o autor deste texto ouviu da então presidente do Condephaat, em uma modesta festa de criança, que não daria aval para a "construção de uma arena para o ego do Zé Celso". Esta manifestação privada tanto da incompreensão desta luta como da impotência que gestores enfrentam hoje nas posições de comando em órgãos de estado resultaria na aprovação das torres por parte do Condephaat pouco tempo depois (CORRÊA, 2013).

No entanto, a ocupação dos terrenos lançou a disputa no campo da cosmopolítica, tornando a questão ecológica, que parecia algo de fundo, o principal tema a ser tratado no momento de se pensar sobre o futuro daquele território.

O Oficina foi convidado a participar, em 2013, da X Bienal de Arquitetura de São Paulo, realizada de forma descentralizada em diferentes pontos da cidade. Dentro da plataforma Modos Colaborativos, as arquitetas do Oficina Marília Gallmeister e Carila Matzenbacher uniram-se a arquitetos belgas e sul-americanos pertencentes a coletivos e na residência denominada Bixiga realizaram, de forma condensada ,todas as etapas e ações necessárias para, em 40 dias, elaborar uma nova proposta para o território, começando por encontros com habitantes, com representantes do bairro e com o próprio grupo Oficina para ouvir expectativas, desejos, necessidades e definir diretrizes. Após as primeiras sessões de escuta, estava definido um programa cultural e teatral e quantificadas as áreas mínimas para sua realização; porém, ficava evidente que sua implantação teria como resultado uma

ocupação do terreno de alta densidade e alto gabarito. A consequência, nesse caso, seria a perda das principais qualidades dessa área: o vazio em pleno centro de São Paulo, sua indeterminação, suas perspectivas visuais dissonantes e seu potencial de estabelecer-se como respiro e campo aberto. (X BIENAL DE ARQUITETURA DE SÃO PAULO, 2013, p. 38)

Partiu-se assim para uma identificação de terrenos na região, fora dos lotes do Oficina e do GSS, tendo como premissas a memória do Rio do Bexiga 
e sua topografia de vale e a morfologia urbana original do bairro, pré-Minhocão. Houve ainda uma roda de conselho com arquitetos de notório saber, entre eles, alguns que já haviam se debruçado sobre as questões do território e foi apresentada a proposta de "explosão" do projeto para fora dos lotes e de preservação dos vazios.

Dois elementos resultantes do projeto devem ser destacados: a intenção de apoiar as pequenas áreas de uso e estar que a população fragmentada do bairro já tinha e a preocupação em incluir uma solução de moradia para as mais de 25 famílias que viviam sob as estruturas do viaduto.

O levantamento geológico realizado então começou a tirar o Rio Bexiga e seu vale escondido do mapa para que surgisse, em uma rede de vias para pedestres e em intervenções pontuais, que ligariam os resíduos da construção do Minhocão, revivescidos como jardins comunitários e viveiros para agricultura urbana, por exemplo. É claro que havia, do lado da companhia e do diretor Zé Celso, a preocupação de que a proposta se limitasse à uma grande intervenção de permacultura, deixando de lado as necessidades propriamente teatrais; no entanto, havia também no projeto as construções de ateliês e de espaços para administração, oficinas e inclusive uma creche, próximas ao Oficina, mas sempre em conexão com aqueles resíduos fragmentados nos arredores e com uma ocupação massiva dos baixos do Minhocão. Ao final, determinou-se um programa bem mais amplo e abrangente do que aquele até então definido pelo Anhangabaú da FelizCidade. E para o estádio de teatro previa-se o vazio, mantido íntegro. Este projeto teve o grande valor de escancarar os limites dos lotes, apresentando possibilidades de intervenção que em nada estariam desconectadas do Oficina, de forma que foi possível retornar a uma ideia de urbanidade que Lina Bo Bardi também tinha em mente quando projetou ao mesmo tempo o Oficina e sua intervenção para o Vale do Anhangabaú, soerguendo o trânsito de automóveis para recriar as vias de pedestres que conectassem diferentes pontos de interesse ao longo dos vales dos rios.

Nos anos que se seguiram, de 2014 a 2017, o Oficina teve de ser extremamente diligente na entrada de representações em diferentes setores e esferas dos Ministérios Públicos para impedir que o projeto das torres da Sisan fosse enfim autorizado. Em 2017, o vereador Gilberto Natalini, do Partido Verde, decidiu transformar a proposta de criação do Parque do Bexiga, a ocupar o 
entorno do Oficina, em projeto de lei para ser votado na Câmara Municipal. A argumentação tramitou e foi marcado o dia da votação, quando algo muito significativo aconteceu. O vereador Fernando Holiday, youtuber negro, assumidamente gay e militante das causas LGBTQI+ e que havia conquistado seu mandato surfando a onda anticorrupção enquanto coordenava o Movimento Brasil Livre - um dos grandes responsáveis pela atual ascensão da extrema direita brasileira após o impeachment de Dilma Rousseff -, apresentou ao plenário um vídeo de $O$ Banquete, de Platão, peça que o Oficina apresentava desde 2009, pretendendo que os demais vereadores soubessem que tipo de coisa se pretendia fazer no Parque do Bexiga, mesmo que ele próprio jamais tenha pisado a pista do Oficina. Na cena, Sócrates incarnado em Zé Celso, canta o "Soneto do Olho do Cu", enquanto lubrifica o orifício anal de outra personagem e nele introduz o dedo anelar. A música é de Zé Miguel Wisnik, mas a letra é uma ode à "franzida e obscura flor" escrita a quatro mãos pelos amantes Rimbaud e Verlaine. Diz-se que, no momento preciso da penetração anal, o vídeo havia sido tirado de foco, quem sabe para evitar que o vereador sofresse uma acusação de falta de decoro. O escândalo paralisou a votação. Eduardo Suplicy fez questão de levar o Oficina ao gabinete de Holiday, em busca de conciliação. Lá, convidado a estar presente em uma das próximas encenações do grupo, o vereador declinou alegando que vomitaria, incapaz de suportar o que se apresentasse a ele. Essa pequena história revela quão mais embaixo está o buraco do cu-desate. Para completar o que se poderia definir como fim de um ciclo ilusório, em reunião com o GSS no SBT, mediada pelo então prefeito de São Paulo, João Dória, realizada com o intuito de buscar novas possibilidades de conciliação, Silvio Santos sugeriu, carregado de sua ironia chula, que fosse criado nos terrenos vazios um "crackódromo" para os dependentes químicos que perambulam pela cidade, desde que Prefeitura e Estado desistiram das políticas de redução de danos e desalojaram o fluxo, emendando ainda que era hora de Zé Celso "parar de sonhar, deixar de ser artista, porque ninguém, nem Prefeitura, nem Estado, nem União dariam a ele o terreno, assim, de mão beijada" (PARA VER A LUZ..., 2019).

O fim deste ciclo de ilusões significou, para o Oficina, o chamado de um novo ator político, o Terrestre, um atrator, como o define Latour (2020), para o qual será inevitável girar os vetores que sempre guiaram disputas similares 
a essa. O abre-alas é o Rio Bexiga. A partir de 2018, estabeleceu-se um laboratório, escritório temporário coordenado pelo arquiteto Milton Massafumi e formado com as arquitetas do Oficina e com Marcelo $X$ além de estudantes da Escola da Cidade. O propósito de abrir o rio, cujo vale está escondido há quase cem anos, passou a ser o principal. A partir da devolução do rio ao território, ao menos no trecho em que ele cruza os terrenos em disputa, elabora-se uma estrutura simples que permita o trânsito de pedestres pela área e a implantação de "teatros de estados", bem servidos tecnicamente, mas aproveitando o desnível total de 14 metros desde a Rua Santo Amaro até o "umbigo do Bexiga", ponto mais baixo do vale, para estabelecer as relações entre público e cena. Assim como a Cesalpina rompeu os limites da pista do Oficina e deu ao teatro a chance de realizar os mais férteis e profícuos encontros com o público enquanto ocupava os terrenos do entorno, o Rio Bexiga terá o papel de romper os limites dos terrenos que resultaram da especulação imobiliária de um grupo empresarial e apresentar ao bairro as novas possibilidades que se criaram em mais de 60 anos de existência - número de uma maioridade que o Oficina alcançou em 2018, e que, ao expressar um ponto de virada na vida humana os japoneses vestem-se de crianças quando se tornam sexagenários -, significará o momento do atrator Terrestre tomar conta dessa Luta.

O projeto de lei para criação do Parque Bexiga enfim foi aprovado pela Câmara Municipal, em fevereiro de 2020, mas seria vetado pelo prefeito em exercício, Eduardo Tuma, no mês seguinte. A Prefeitura alegou que a decisão extrapolava os limites da ação do Legislativo, que não havia vegetação remanescente do bioma Mata Atlântica que justificasse a criação do parque e que a administração municipal não teria os recursos necessários "para fazer frente à despesa de grande vulto decorrente da criação e manutenção do cogitado parque" (VIEIRA, 2020).

aos poucos, eis que sob o solo da propriedade privada, do monopólio das terras, da exploração dos territórios, um outro solo, uma outra terra, um outro território começou a se agitar, a tremer, a se comover. Uma espécie de terremoto, se preferir, com o seguinte recado àqueles pioneiros: Prestem atenção, nada será como antes; vocês pagarão caro pelo retorno da Terra, pela reviravolta dos poderes que até agora eram dóceis.

Bruno Latour, Onde aterrar? 


\section{Referências bibliográficas:}

ANHANGABAUDAFELIZCIDADE. Parecer de Jurema Machado - Tombamento do Teatro Oficina. anhangabaudafelizcidade, São Paulo, 19 abr. 2012. Disponível em: http://bit.ly/3rMS2vp. Acesso em: 12 fev. 2021.

BO BARDI, L. [Contracapa]. In: FERRAZ, M. C. Lina Bo Bardi. 5a. ed. São Paulo: Instituo Bardi/Casa de Vidro, 2018.

CORRÊA, J. C. M. Carta Aberta a Presidente do Iphan, Ana Lanna. Blog do Zé Celso, São Paulo, 26 set. 2013. Disponível em: http://bit.ly/2Mml9a1. Acesso em: 3 fev. 2021.

GALVAN, J. [Portfolio]. Issuu, Palo Alto, 23 fev. 2017. Disponível em: http://bit.ly/3u3dvSW. Acesso em: 12 fev. 2021.

JBMC ARQUITETURA \& URBANISMO. [Projeto para o Teatro Oficina]. São Paulo: JBMC Arquitetura \& Urbanismo, 2011. Disponível em: http://bit.ly/3d85PZm. Acesso em: 12 fev. 2021.

LATOUR, B. Onde aterrar? Como se orientar politicamente no Antropoceno. Rio de Janeiro: Bazar do Tempo, 2020

PIANCA, G. Teatro de estádio: Expansão do teatro Oficina. 2012. Trabalho de Conclusão de Curso (Graduação em Arquitetura e Urbanismo - Faculdade de Arquitetura e Urbanismo, Universidade de São Paulo, São Paulo, 2012. Disponível em: http://bit.ly/ 2O3f215. Acesso em: 3 fev. 2021.

VIEIRA, B. M. Prefeito em exercício, Tuma veta criação do Parque Bixiga. G1 São Paulo, São Paulo, 174 mar. 2020. Disponível em: http://glo.bo/3pg6jio. Acesso em: 12 fev. 2021.

X BIENAL DE ARQUITETURA DE SÃO PAULO. Cidade: modos de fazer: modos de usar: modos de colaborar. São Paulo: X Bienal de Arquitetura de São Paulo, 2013.

Autor convidado 
